\title{
INTERRELIGIOUS DIALOGUE FOR CONFLICT PREVENTION
}

\author{
${ }^{1}$ Ahmad Zarkasi, ${ }^{2}$ Idrus Ruslan, ${ }^{3}$ Agustam, ${ }^{4}$ Syafrimen Syafril, ${ }^{5}$ Azhar Jaafar@Ramli, ${ }^{6}$ Engkizar \\ Engkizar, ${ }^{7}$ Zainuddin \\ 1, 2, 3, 4 Universitas Islam Negeri Raden Intan Lampung, Indonesia, ${ }^{5}$ Kolej Yayasan Pahang, Malaysia, ${ }^{6}$ Universitas \\ Negeri Padang, Indonesia, ${ }^{7}$ Institut Agama Islam Negeri Batu Sangkar, Indonesia \\ Correspondence: Syafrimen Syafril. E-mail: syafrimen@radenintan.ac.id
}

\begin{abstract}
Interreligious dialogue possesses external and internal critical functions. Such dialog promotes a new resolution for sustainable community as stable and dynamic interreligious understanding and its application are gained among the plural society. The objective of the study is to reveal whether the interreligious dialogue is potential in managing conflict prevention. The research uses multi case single-site exsploratory case study. Primary data was collected through observation as well as snowballing technique indepth interview conducted to village leaders and religious leader in PunduhPidada, District of Pesawaran in which the community is religiously diversed. They come from various religions; Islam, Christian and Catholic.While secondary data is obtained through document analysis of various religious books, holy books and any documents related to the study. Data was qualitatively analyzed by the helping of NVIVO 10 software.Of the analysis, it is revealed that (i) the interreligious dialogue occurs through social activities, (ii) community habits and awareness in doing teamwork, (iii) support of both village leaders and religious leaders. The findings of the study is correlated with theories and previous research findings that the interreligious dialogue can be a reference in creating peace, harmony, tranquility and respect among the diversed community.
\end{abstract}

Keywords: Interreligious Conflict, Conflict Prevention, Sustainable community, Dynamic interreligious, Multi case single-site exsploratory case study

\section{Introduction}

Indonesia is really well-known for its pluralism in religion. Interreligious relation among the community is dynamic and colored by conflict in local, regional or even national level (Husaini, 2005, p. 33). Each religion conceptually promotes teaching of peace, harmony, tranquility, and respect, however, such religious concepts are not historically wellimplemented as dreamed of the followers (Fidiyani, 2013, p. 469). Thus, an appropriate instrument to make the idea of religion teaching comes true shall be founded and it is "dialogue".

Dialogue is described as opennes view among people who care to each other. Interreligious dialogue is regarded as harmonious atmosphere as there are positive perspective and approach between two parties. Dialogue will lead to harmony and mutual understanding (Panikkar, 1994, p. 34; Majid, 1998, p. 6). Ideally, it is expected that the dialogue is not merely a life style, but also life perspective (Hidayat, \& Gaus, 2005.p.7). Dialogue is not winning-oriented but it is a platform to foster mutual understanding that universal consensus can be achieved. Moreover, it can be regarded as a tool of communication to bridge cultural misunderstanding (Cush \& Robinson, 2014, p. 12; Halsall, \& Roebben, 2006, p. 448). 
Dialogue is not merely aimed at living together peacefully and full of tolerance among different religion followers, but also actively participate for other religious existence (Huda, 2006, p. 189). The most important thing is that the orientation of the dialogue to gain coexistence and pro-coexistence. Coexistence is aimed at creating tolerance while the objective of pro-existence to find out the similarities of doctrines among the different religions, tradition, spirit and history as well as to find the differences that conflict potential can be minimized (Izzah, 2013, p. 18). Dialogue is pivotal in avoiding arrogancy, aggresivity, and other negative attitude and perspective of the followers in spreading the teachings of their religions (Abidin, 2015, p. 83). Thus, dialogues can be primary instrument for community to live peacefully in a democratic country.

Dialogue is not problem-free. There have been thousand agressive acts performed by the fanatic followers of certain religions like firing worshipping sites or places, vandalism, and looting of sacred sites of certain religions (Mustofa, 2017, p. 78). As the pluralism of religions and beliefs in Indonesia cannot be questioned anymore, dialogue is regarded as the the most appropriate and ideal way for interreligious conflict resolution (Suryana, 2011, p. 130). Interreligious conflict has undoubtedly negative effect to social life of a community. Thus, dialogue can be a perfect solution to be a conflict resolution as well as conflict prevention. This way has been perefectly implemented by a small yet plural society in Bangun Rejo Village Punduh Pidada sub-district.

Village of Bangun Rejo belong to Punduh Pidada sub-district area in District of Pesawaran. The community in this village embraces various religions, namely Islam, Christian and Catholic.The number of Muslim community is 1279 ; consisted of $55 \%$ of Lampungnese (Malay), and 45\% Javanese. There are 120 Christian whose ethnicity is Javanese and 119 Catholic followers who are also Javanese living in the village (Interview with the village prominent figure, Former of Head of Bangun Rejo, on 28 February 2016). The three religions are categorized missionary religions (Hasenclever \& Rittberger, 2000, p. 644). Thus, as the three religions are categorized as missionary religions, there must be doctrine of orders to spread the teachings of the religions revealed in the Holy Books. The failure or ignorance of the followers in spreading their religions principles and teaching will lead to religious sanction or punishment. However, if the teachings and principles are obediently and consistently spreaded by the followers, they will get reward, good deeds and heaven in return. The activities in spreading the religious teachings and doctrines are truly conflic potential that religious riots cannot avoided.

It is quite interesting that the comunnity in the village of Bangun Rejo is settled by a community who embraces the three missionary religions, however, they could live harmoniously and peacefully hand in hand. Religious conflict and riot can be avoided. As it is stated by one of the religious leader in the village, "we have been living here peacefully, there is no interreligious conflict at all" (Interview with a Religious Leader of Bangunrejo, on 27 February 2016). Similarly, another prominent character also stated, " in every religious holy days, we usually visit each other. When there is a family who get disaster, or have a family party, other families and neighbor will come and help each other" (Interview with Patrick Suyanto, A Christian Figure, on 27 February 2016). Further, one of the settlers said, " we truly respect others in here. When one celebrate his/her Holy Day, we have tradition to congratulate each other by paying a visit. We do not feel awakward in doing the tradition" (Interview with Wati "a Muslim", on 27 February 2016). Another also said, "I have never experienced religious conflict or riot since I was little in here" (Interview withThomas Ribut Sampurno, on 27 February 2016). Based on the explanation it can be drawn that the people 
always promote interreligious dialogue that it can minimize the inter-faith conflict. The research was conducted to exclusively find out the interreligious dialogue in preventing interfaith conflict in Bangun Rejo Village.

\section{Research Methodology}

The research belongs to qualitative study(multi case single-site exsploratory case study); a study to find out a phenomena in a community (Yin, 2013; Creswell \& Clark, 2005), to study facts through observation and interview in the field as well as related document as data. Data in this study refer to existed indication and tendency, indicated by interaction and communication among the community through formal and informal dialogue among the community of Bangun Rejo village which consists of Muslim, Christiam and Catholic followers. Primary data was collected through observation with Snow Balling Process through indepth interview with village leaders as well as the religious leaders in sub-district Punduh Pidada, Kabupaten Pesawaran. Secondary data was obtained through document analysis on various Holy Books, religious book and nay documents related to the study. The data was then thematically analyzed through the help of NVIVO 10 software (Braun \& Clarke, 2012, p. 23). According to Rowley (2002) and Costello, \& Osborne (2005) exsploratory case studyis aimed at exploring and giving comporehensive description of individual, tendency, or certain group by presenting the data scientifically.

\section{Findings and Discussion}

The findings of the study reveals that there are some characteristics of interreligious dialogue in Bangun Rejo village, namely; (i) the dialogue occurs during social activities. The community holds various cooperative work in doing infrastructure work, improving family life quality, charity activities in helping those who are in proverty, famine, and refugee. They are also working on gender equity, human right and peace.(ii) Community habits and awaraness in building teamwork, (iii) both formal and non formalsupport from village prominent figures and religious leaders. Formal support is orally delivered in every meeting advising that the peaceful and harmonious atmosphere in the village shall be maintained. Nor formal support is usually delivered in non formal situation in the village emphasizing the importance of living in harmonious atmosphere.

Referring to Banawiratma, it can be concluded that the interreligious dialogue among Muslim, Christian and Catholic at least occurs during social interaction in Bangun Rejo village (Social analysis and contextual ethic reflection). The dialogue occurs where diversed community is able to interpret the factual reality and draw an ethical decision (Banawiratma, $2010 \&$ Ahmad, 2013). Followers of any religions are able to cooperate in conducting various activities among the community, yet the dialogue is expected to improve humans' value and dignity as well as their integral freedom. As the village prominent figures states that the diversity of religions does not become the cause of conflict and riots in the village. The community possesses deep tolerance and deep understanding in performing their and others' religious worship and activities that mutual respect among the followers of the different religions can be achieved (Interview with Mr. Agus Wahyudhi, on 09 August 2016).

Similar statement is also proposed by Zamhari. The diversity in religion will not become an obstacle for the community to perform their peaceful social community life. Teamwork and 
mutual visit are commonly perfomed in their daily basis as those practices are not regarded as worship part in a narrow perspective (Interview with Mr.Zamhari "Muslim figures" on 10 August 2016). Further, Christian prominent figures in the village also stated that the religious conflict and riot rarely occur in the village as the community has already had high awareness on the importance of peaceful living among peple who are from distinctive religious background (Interview with Mr. Sugiantoro "Christian Figure”, on 10 August 2016)

The previous description shows that tolerant and harmonious religious atmospehre as well as social dialogue among the community have been well-perfomed. In this context, dialogue conducted by the community is described as practical cooperation which is related to the theory of dialectical pluralism (Anna, 2016, p. 259; Ghazali, 2000). According to Daradjat (1996) and Ghazali, (2017) proposes four characteristics, namely: First, confessionalist emphasizing the importance of commitment in faith, the confession of faith theologically and practically including finality claim, a claim in which the truth claim has to be positioned in dialectical context and pluralism situation demand. Second, pluralism in every religion should be viewed as concrete totality and let the religion maintain their own confession term without any reduction or subordination. Third, dialectical history among religions possess concrete relation in history in form of differentiation, contradiction, and reconciliation toward the changes of humans' perspective and knowledge. Fourth, human solidarity becomes the most important agenda among distintions possessed by each party. Interreligious dialogue becomes possible to be conducted when the followers appreciate, respect and tolerate others. Narrowminded attitude will undoubtedly hinder the dialogue.

Although most of the settlers come from diversed ethnic group, they share same language in their daily basis. The new comers (Javanese and Malay of South Sumatera) adapt themselves with the local language. This becomes another reason the closeness among the settlers in th village. The pattern of interreligious dialogue is called symbolic interaction. This theory views individual as a product determined by the surrounding community. Symbolic interaction pattern can be detected when they interact to understand and interpret their feeling when they are interacting. They could correctly intepret the local idioms and wise words uttered by others. The new comers try to understand the local wisdom and interpret it into respective attitude.

The community and village officials realize that they live peacefully side by side though they are ethnically and religiously distinctive. The spirit of teamwork and togetherness is kept among the community. As it is stated by Head of Community Welfare Affairs in the village that there are a lot of cooperation conducted by the diversed community like gotong royong, arisan and jimpitan (Interview with a public figure village Bangun Rejo, on 21 August 2016). Besides, the atmosphere of mutual respect and appreciation has been built. When Muslim people celebrate their Holy Day, Christian and Catholic community provide conducive spaces for the Muslim to practice their worship peacefully. Similarly, when the Christians and Catholics celebrates their Holy Days, Muslims also respect and give peaceful atmosphere to those people.

The comfortable tolerant atmosphere is supported by the religious leader and village figures who spread the awareness to the community that mutual respect is pivotal in creating peaceful religious condition. The lecture of the importance of mutual respect among the settlers is always delivered by the village figures in any chances like in worshipping places, wedding functions, and village meeting. The religious leaders remind people to hold activities that promotes togetherness like arisan and gotong royong (Interview with a figure public 
village Bangun Rejo, on 21 Agustus 2016). The study reveal that community, religious leader and village figures have realized that the religious aspects are not merely centered on performing the religious ritual and worship, but also living peacefully hand in hand with other people from different religious and cultural backgorund. According to al Munawar (2003, p. 59) harmonius life will be created if two attitudes are performed. First, mutual respect and appreciation are unconsciously performed. Second, respecting others is not for certain political interest but because of the personal awareness that religions in the world basically have teaching similarities in respecting others.

The first attitude is built through dialogue and promoting tolerant as well as hinder the issues of Tribe, Religions, Race and Ethnicity. Implicitly, such behavior is mostly fragile that the followers can be provoked when their religious emotion is attacked. In another side the attitude will possibly lead to dishonesty in diversity concencus. For example, follower who are politically and financially strong oppress those who are weak through humanity and peace activities. The second attitude is likely based on the religious awareness that there is basic teaching among the religions to respect others, to be objective and to hinder prejudice. The deep learning of other religions will lead to objective justification of a certain religion. Bias can be surely avoided. The deep knowledge will lead to honesty and will not sacrifice good interreligious relation. The second attitude is likely more potential for religious issues in future.

The theory can be related to the research. It is revealed that the implementation of interreligious dialogue is based on the first attitude. Most of the community in the village work as farmers and have low level of education that the deep understanding of interreligious knowledge as prescribed in the second attitude cannot be achieved. However, all practices and efforts to promote the interreligious dialogue should be appreciated. Continous support and guidance from both parties; the village figures and religious leaders is highly needed that the awareness of building harmonious and peaceful interfaith life can be gained. Beside the community is not fragile in building the religious life. The interreligious dialogue occurs because of great communication among Muslim, Christian and Catholic. The communication can be personal and in a community group. Positive communication will lead to beneficial interaction. In context of the research, people awareness to respect other faiths can be a strong factors in implementing interreligious dialogue. Habits of respecting others creates community with high emphaty (Murniyetti, Engkizar, \& Anwar, 2016; Syafril, Ishak, Erlina, 2017).

Religious leaders spread the teaching about the importance of maintaining the peacful interreligious life through sermons and religious rituals. While the village figures deliver the support through village formal forums like in village meeting. Moreover, the area similarities is another factor to suppor such dialogue. Imitation factor also plays important role in keeping the harmonious life in the village that a person or a group will imitate other attitude. Muasim informed that they copy the farming techniques of those who are regarded creative in developing their palnting technique that their crops can be increased (Interview with Muasim, a Muslim, on 21 August 2016).

Sympathy is also another factor in maintaining the harmonious life. When another community member gets an accident, other neighborhood will immediately offer their help by visiting the house and giving material and non-material help (Komter, 2005). Similarly, when another community member hold a function, the immediate neighborhood will come to help the preparation of the party. Such action in sociology is regarded as sympathy factor in 
an interaction (Kahmad, \& Cuanda, 2000; Qodir, 2011). The attitude culturally promote the peaceful and harmonious atmosphere in a community.

\section{Conclusion}

Diversity in religions, faiths and ethnics is not regarded as an obstacle to pay mutual respect in community. This study reveals that interreligious dialogue can be an effective instrument in preventing conflict in a society. Positive interaction through the dialogue has to be maintained that the possibility of conflict can be hindered. In this case it is regarded as a preventive effort to minimize the conflict. All parties are expected to realize their limitations required by religions. In this context, all religious leaders and officials are expected to give a clear guidelines of true meaning of interreligious dialogue that interreligious sincretisme can be avoided.

\section{Acknowledgements}

Our highest appreciation is addressed to Institute for Research and Community Services of UniversitanRadenIntan Lampung which has given numerous financial financialsupports in completing this research. The study is funded through Budget Implementation Checklist in 2016, based on Decree of Rektor No. 311 Year 2016 related to determination of research title, name of the researcher and research group for lecturer IAIN RadenIntan Lampung in 2016.

\section{References}

Ahmad, H.A. (2013). Survei nasional kerukunan umat beragama di Indonesia. Kementerian Agama RI, Badan Litbang dan Diklat, Puslitbang Kehidupan Keagamaan.

Al Munawar, S. A. H., \& Halim, A. (2003). Fikih Hubungan Antar Agama. Jakarta: Ciputat Press.

Anna, D. N. (2016). Peran integratif agama-agama dalam mengatasi masalah kemiskinan di Banjarasri Kalibawang Kulonprogo Daerah Istimewa Yogyakarta dengan pendekatan sosiologi dan psikologi. Religi Jurnal Studi Agama-Agama, 10(2), 259-278.

Banawiratma, J. B. (2010). Dialog antarumat beragama: gagasan dan praktik di Indonesia, Bandung: Penerbit Mizan.

Braun, V., \& Clarke, V. (2006). Using thematic analysis in psychology. Journal Qualitative Research in Psychology, 3(2), 77-101.

Costello, A. B., \& Osborne, J. W. (2005). Best practices in exploratory factor analysis: Four recommendations for getting the most from your analysis. Practical Assessment, Research \& Evaluation, 10(7), 1-9.

Creswell, J. W., Clark, V.L.P., (2005). Mixed Methods Research Designs in Counseling Psychology. Journal of Counseling Psychology, 52(2), 224-234..

Cush, D., \& Robinson, C. (2014). Developments in religious studies: towards a dialogue with religious education. British Journal of Religious Education, 36(1), 4-17.

Daradjat, Z. (1996). Perbandingan Agama. Jakarta: Bumi Aksara.

Fidiyani, R. (2013). Kerukunan Umat Beragama di Indonesia (Belajar Keharomonisan dan Toleransi Umat Beragama di Desa Cikakak, Kec. Wangon, Kab. Banyumas). Jurnal Dinamika Hukum, 13(3), 468-482. 
Ghazali, A. M. (2017). Teologi Kerukunan Beragama dalam Islam (Studi Kasus Kerukunan Beragama di Indonesia). ANALISIS: Jurnal Studi Keislaman, 13(2), 271-292.

Ghazali, A.R. (Ed.). (2000). Etika agama dalam membangun masyarakat madani. Logos Wacana Ilmu.

Halsall, A., \& Roebben, B. (2006). Intercultural and interfaith dialogue through education. Religious Education, 101(4), 443-452.

Hasenclever, A., \& Rittberger, V. (2000). Does religion make a difference? Theoretical approaches to the impact of faith on political conflict. Journal Millennium, 29(3), 641-674.

Hidayat, K., \& Gaus, A. F. (2005). Ahmad. Passing Over: Melintasi Batas Agama.

Huda, Q. U. (2006). Conflict prevention and peace-building efforts by American Muslim organizations following September 11. Journal of Muslim Minority Affairs, 26(2), 187-203.

Husaini, A. (2005). Pluralisme agama: haram: fatwa MUI yang tegas \& tidak kontroversial. Pustaka Al-Kautsar.

Izzah, L. (2013). Melihat Potret Harmonisasi Hubungan Antarumat Beragama di Indonesia. Religi Jurnal Studi Agama-Agama, 9(1), 1-22.

Kahmad, D., \& Cuanda, C. (2000). Sosiologi agama. Remaja Rosdakarya.

Komter, A. E. (2005). Social solidarity and the gift. Cambridge University Press.

Madjid, N. (1998). Dialog Agama-agama dalam Perspektif Universalisme al-Islam. Dalam Pasing Over: Melintas Batas Agama. Jakarta: Gramedia Pustaka Utama.

Murniyetti, Engkizar, \& Anwar, F. 2016. Pola Pelaksanaan Pendidikan Karakter Terhadap Siswa Sekolah Dasar. Jurnal Pendidikan Karakter, 6(2),157-166.

Mustofa, I. (2017). Terorisme: Antara Aksi dan Reaksi (Gerakan Islam Radikal sebagai Respon terhadap Imperealisme Modern). Journal Religia, 15(1), 66-87.

Panikkar, R. (1994), Dialog Intra Religius, Yogyakarta: Kanisius.

Qodir, Z. (2011). Sosiologi agama: esai-esai agama di ruang publik. Pustaka Pelajar.

Rowley, J. (2002). Using case studies in research. Management Research News, 25(1), 16-27.

Yin, R. K. (2013). Applications of case study research. Newbury Park: SAGE Publications. 